\title{
Impact of parity and gestational age of mothers with hypertension on birth weight, red blood cells and mode of delivery of their babies
}

\author{
Helen Chioma Okoye ${ }^{1}$, Chilota Chibuife Efobi ${ }^{2}$, Josephat Maduabuchi Chinawa ${ }^{3}$, \\ Odutola Israel Odetunde ${ }^{3}$, Awoere Tamunosiki Chinawa ${ }^{4}$, Elias Chikee Aniwada ${ }^{5}$
}

1. Department of Haematology and Immunology, College of Medicine, University of Nigeria, Ituku Ozalla campus, Enugu.

2. Department of Haematology and Immunology, College of Medicine, Chukwuemeka Odumegwu Ojukwu Univeesity, Awka.

3. Department of Pediatrics, College of Medicine, University of Nigeria, University of Nigeria Teaching Hospital, Ituku Ozalla, Enugu, PMB 01129, Ituku-Ozalla, Enugu State, Nigeria.

4. Department of Community Medicine, College of Medicine, Enugu State University of science and Technology Enugu.

5. Department of Community Medicine, College of Medicine, University of Nigeria Teaching Hospital, Ituku Ozalla, Enugu, PMB 01129, Ituku-Ozalla, Enugu State, Nigeria.

\section{Emails:}

helenc.okoye@unn.edu.ng; chylowb@yahoo.com; josephat.chinawa@unn.edu.ng; odetoyintola@yahoo.co.uk; eaniwada@gmail.com; chinawa4awoere@gmail.com

\begin{abstract}
Background: Maternal factors are determinants of birth outcome which includes birth weight, haematological indices and mode of delivery of their babies.

Objectives: To determine the impact of parity and gestational age of hypertensive mothers on some neonatal variables.

Methods: A hospital based cross-sectional study of measurement of neonatal variables (birth weight, red blood cells and mode of delivery) among hypertensive mothers and their controls was conducted over a period of six months. Data were analyzed using the Statistical Package for Social Sciences program (SPSS), version 20.

Results: There were statistically significant differences in means between the neonates of the hypertensive group and non-hypertensive group for maternal age $(t=1.61, p=0.002)$, baby weight $(t=2.87, p<0.001)$, haemoglobin $(H b)(t=4.65, p=0.010)$ and packed cell volume $(\mathrm{PCV})(\mathrm{t}=4.75, \mathrm{p}=0.009)$, but none for gravidity $(\mathrm{t}=1.95, \mathrm{p}=0.927)$

For all subjects, there was poor correlation between gestational age and variables; birth weight, haemoglobin (Hb), packed cell volume (PCV), nucleated red blood cell (nRBC) and parity. Likewise, parity poorly correlated with variables; age, birth weight, Hb, PCV, and nRBC. There was a statistically significant association between mode of delivery and hypertension $(\chi 2=53.082, \mathrm{p}<0.001)$ but none with having a family history of hypertension $\left(\chi^{2}=1.13, \mathrm{p}=0.287\right)$.

Conclusion: Parity and gestational age of mothers with hypertension have no impact on birth weight and red cells when compared with their non-hypertensive counterparts. However, mothers of babies delivered by elective and emergency caesarean section were about 2-3 times more likely to be hypertensive than those that delivered through spontaneous vertex delivery.
\end{abstract}

Keywords: Hypertension; neonate; gestational age; parity.

DOI: https://dx.doi.org/10.4314/ahs.v19i4.25

Cite as: Okoye HC, Efobi CC, Chinawa JM, Odetunde OI, Chinawa AT, Aniwada EC. Impact of parity and gestational age of mothers with bypertension on birth weight, red blood cells and mode of delivery of their babies. Afri Health Sci.2019;19(4):3038-3044. https:/ / dx.doi.org/ 10.4314/ abs.v19i4.25

\section{Corresponding author:}

Josephat Maduabuchi Chinawa,

Pediatric Cardiology Unit, Department of Pediatrics, University of Nigeria Teaching Hospital, UNTH, Ituku Ozalla, Enugu. PMB 01129, Ituku- Ozalla, Enugu State, Nigeria.

Phone: +2348063981403

Email: josephat.chinawa@unn.edu.ng

\section{Introduction}

Maternal factors are strong determinants of birth outcomes. Weight at birth, which depends almost entirely on maternal factors, is the single most important factor determining survival and health development of babies. ${ }^{1}$ Birth weight on the other hand is determined by gestational age and fetal growth, a product of both internal (genetic) and environmental factors with placental function as an important environmental factor. ${ }^{2}$ In addition

$\begin{array}{ll}\text { African } & \text { (c) } 2019 \text { Okoye et al. Licensee African Health Sciences. This is an Open Access article distributed under the terms of the Creative commons Attribution License } \\ \text { Health Sciences } & \text { (https://creativecommons.org/licenses/BY/4.0), which permits unrestricted use, distribution, and reproduction in any medium, provided the original work } \\ \text { is properly cited. } & \end{array}$ 
to length of gestation, other known maternal factors include socio-demographics, parity/gravidity as well as maternal health.3,4 In most cases, growth variatios in different population of fetuses are due to differences in environmental factors. 2

Hypertension is one of the commonest medical complications of pregnancy with an incidence of $17 \%$ in Nigeria.5 It significantly contributes to maternal morbidity and mortality. Hypertensive disorders of pregnancy impacts negatively on fetal outcome of which uteroplacental compromise is an important mechanism. The fetal outcome is also dependent on the degree and type of hypertension in pregnancy.6,7 Studies have shown diverse fetal/neonatal complications of maternal hypertension some of which are intrauterine growth restriction, preterm births, fetal demise and haemogram derangement.8,9 Notable haematological complications include polycythaemia, neutropenia and thrombocytopenia.10 Different researchers have come up with conflicting reports as to the likelihood and magnitude of adverse birth outcome due to some maternal or environmental factors.

This study aimed to determine the impact of parity and gestational age of hypertensive mothers on some neonatal variables with special reference to the birth weight, haemoglobin $(\mathrm{Hb})$, packed cell volume (PCV), nucleated red cells (nRBC) and mode of delivery of these newborns.

\section{Methodology}

This is a hospital-based cross-sectional study conducted at the University of Port Harcourt Teaching Hospital (UPTH), a Federal Government owned tertiary institution in Rivers state, Nigeria. The Hospital is an 800-bed tertiary centre in Port Harcourt, the state capital. Port Harcourt is also the centre of oil and gas in Southern region of Nigeria with a population projected to be over 700,000. As one of the major tertiary institutions in the Niger-Delta region of Nigeria, its attracts different classes of patients and serves as a referral centre for neighboring states which include Bayelsa, Delta, Imo, Abia states.

Study Population: A total of 200 neonates were recruited for the study, 100 of whose mothers had hypertension in pregnancy and another 100 full term apparently healthy neonates born to normotensive mothers, without maternal complications. They were recruited by a systematic random sampling method through the labour wards and theatres of the obstetrics section of the hospital. A pro- forma was developed to collect data on demographics, obstetrics and medical history of their mothers. Data on birth outcomes were also sought for which include mode of delivery and birth weight. Neonatal samples were collected for a $\mathrm{Hb}$ and PCV estimation as well as peripheral blood film for $\mathrm{nRBC}$, procedure as already explained in literature. Subjects who were products of multiple gestation or whose mothers had evidence of renal or heart disease, diabetes mellitus, history of chronic pulmonary disease or smoking were excluded from the study. Also excluded were asphyxiated babies, neonates who underwent delayed cord clamping, cord milking, held below the level of maternal introitus during delivery or had congenital anomalies.

Ethical considerations: The study was carried out in accordance with the ethical standards of the UPTH ethical committee and with the Helsinki Declaration. Parents or caregivers of the neonates gave their informed consent before recruitment.

\section{Sample size calculation}

The sample size was calculated using the formula below for each of the groups

$\mathrm{N}=\mathrm{C} \pi(1-\pi 1)+\pi 2(1-\pi 2) /(\pi 1-\pi 2)$

$\mathrm{N}=$ Minimum sample size of each group

$\pi 1=$ Proportion of neonates from mothers diagnosed and managed for hypertension $(20 \%=0.2)$

$\pi 2=$ Proportion of neonates from non-hypertensive mothers $(40 \%=0.4)$

$\mathrm{C}=$ Constant $=7.9$

$\mathrm{N}=79$

Attrition of $10 \%$ was taken for each group making a total of 16 new participants ( 8 in each group i.e 87), The total number was made up to 100 per group since 87 per group was the minimum.

\section{Data analysis}

Data were analyzed using the Statistical Package for Social Sciences (SPSS) software version 20. Results were presented in tables and charts as mean \pm standard deviation (SD) and percentages. Student T-test was used as appropriate to compare the means of numerical parameters. Pearson Correlation Coefficient was used to establish relationship between GA and parity with other variables. Pearson Chi square test and Binary Logistic Regression were used to assess association and determinants of hypertension. Confidence interval was set at 95\%. 


\section{Results}

Table 1 shows that there were statistically significant differences in means between the neonates delivered by hypertensive mothers and those of non-hypertensive mothers for maternal age $(t=1.61, p=.002), G A(t=7.41, p<$
$0.001)$, parity $(\mathrm{t}=0.96, \mathrm{p}=0.036)$, baby weight $(\mathrm{t}=2.87, \mathrm{p}$ $<0.001), \mathrm{Hb}(\mathrm{t}=4.65, \mathrm{p}=0.010)$ and PCV $(\mathrm{t}=4.75, \mathrm{p}=$ $0.009)$. There was no statistically significant difference in means between those with hypertension and those without hypertension for gravidity $(t=1.95, \mathrm{p}=0.927)$

Table 1: Comparison of characteristics by presence or absence of maternal hypertension

\begin{tabular}{|l|c|c|c|c|c|}
\hline Variable & Number & Mean & $\begin{array}{c}\text { Std } \\
\text { Dev }\end{array}$ & T test & $\begin{array}{c}\text { p } \\
\text { value }\end{array}$ \\
\hline & & & & & \\
\hline HTN & 100 & 31.73 & 4.05 & 1.61 & 0.002 \\
\hline No HTN & 100 & 30.65 & 5.34 & & \\
\hline Gravidity & & & & & \\
\hline HTN & 100 & 3.58 & 1.65 & 1.95 & 0.927 \\
\hline No HTN & 100 & 3.13 & 1.61 & & \\
\hline & & & & & \\
\hline Gestational age & & & & & \\
\hline HTN & 100 & 32.85 & 7.54 & 7.41 & 0.000 \\
\hline No HTN & 100 & 38.64 & 2.05 & & \\
\hline & & & & & \\
\hline Parity & & & & & \\
\hline HTN & 100 & 1.48 & 1.21 & 0.96 & 0.036 \\
\hline No HTN & 100 & 1.66 & 1.44 & & \\
\hline & & & & & \\
\hline Baby Weight & & & & & \\
\hline HTN & 100 & 2.98 & 0.80 & 2.87 & 0.000 \\
\hline No HTN & 100 & 3.25 & 0.48 & & \\
\hline PCV & & & & & \\
\hline HTN & & & & & \\
\hline No HTN & 100 & 51.06 & 9.02 & 4.75 & 0.009 \\
\hline HB & 100 & 45.49 & 7.50 & & \\
\hline HTN & & & & & \\
\hline No HTN & 100 & 16.55 & 3.06 & 4.65 & 0.010 \\
\hline nRBC & 100 & 9.43 & 8.76 & MWU* & 0.001 \\
\hline HTN & 100 & 5.44 & 4.32 & & \\
\hline No HTN & & & & & \\
\hline
\end{tabular}

MWU* --Man Whitney U test, HTN -Hypertension, No HTN -No Hypertension, HB - hemoglobin, $\mathrm{nRBC}-$ nucleated red blood cells. T test - student $\mathrm{T}$ test.

Table 2 shows that for those whose mothers have hypertension, there were poor correlations between GA and variables; age $(\mathrm{r}=0.18)$, baby weight $(\mathrm{r}=0.19), \mathrm{Hb}(\mathrm{r}=$ $0.19), \operatorname{PCV}(\mathrm{r}=0.18)$, nucleated red blood cell (nRBC) $(\mathrm{r}$
$=0.04)$ and parity (rhor $=0.16)$. Likewise, the non-hypertensive counterparts showed poor correlations between GA and variables; age $(r=0.12)$, baby weight $(r=0.05)$, $\mathrm{Hb}(\mathrm{r}=0.15), \mathrm{PCV}(\mathrm{r}=0.11), \mathrm{nRBC}(\mathrm{r}=0.09)$ and parity $($ rho $=0.13)$. 
Table 2: Correlation between gestational age and parity with other characteristics for neonates of hypertensive mothers

\begin{tabular}{|l|c|c|c|c|c|}
\hline Variable & Number & Mean & $\begin{array}{c}\text { Std } \\
\text { Dev }\end{array}$ & r & $\begin{array}{c}\text { p } \\
\text { value }\end{array}$ \\
\hline Gestational age & 100 & 32.85 & 7.54 & -0.18 & 0.07 \\
\hline Age & 100 & 31.73 & 4.06 & & \\
\hline & & & & & \\
\hline Gestational age & 100 & 32.85 & 7.54 & 0.19 & 0.060 \\
\hline Baby Weight & 100 & 2.98 & 0.80 & & \\
\hline & & & & & \\
\hline Gestational age & 100 & 32.85 & 7.54 & -0.19 & 0.056 \\
\hline HB & 100 & 16.55 & 3.06 & & \\
\hline & & & & & \\
\hline Gestational age & 100 & 32.85 & 7.54 & -0.18 & 0.077 \\
\hline PCV & 100 & 51.06 & 9.02 & & \\
\hline & & & & & \\
\hline Gestational age & 100 & 32.85 & 7.54 & 0.04 & 0.717 \\
\hline nRBC & 100 & 9.43 & 8.76 & & \\
\hline & & & & & \\
\hline & Number & Mean & Std & rho & p \\
& & & Dev & & value \\
\hline Gestational age & 100 & 32.85 & 7.54 & 0.16 & 0.105 \\
\hline Parity & 100 & 1.48 & 1.21 & & \\
\hline & & & & & \\
\hline Parity & 100 & 1.48 & 1.21 & 0.12 & 0.256 \\
\hline Age & 100 & 31.73 & 4.06 & & \\
\hline & & & & & \\
\hline Parity & 100 & 1.48 & 1.21 & 0.11 & 0.300 \\
\hline Baby Weight & 100 & 2.98 & 0.80 & & \\
\hline & & & & & \\
\hline Parity & 100 & 1.48 & 1.21 & 0.12 & 0.230 \\
\hline HB & 100 & 16.55 & 3.06 & & \\
\hline Parity & 100 & 1.48 & 1.21 & 0.09 & 0.398 \\
\hline PCV & 100 & 51.06 & 9.02 & & \\
\hline & & & & & \\
\hline Parity & 100 & 1.48 & 1.21 & 0.18 & 0.078 \\
\hline nRBC & 100 & 9.43 & 8.76 & & \\
\hline & & & & & \\
\hline & & & & & \\
\hline & & & & & \\
\hline & & & & & \\
\hline & & & & & \\
\hline & & & & & \\
\hline & & & & & \\
\hline
\end{tabular}

r - Pearson Correlation Coefficient, rho - Spearman Correlation Coefficient, nRBC - nucleated red blood cells, HB - haemoglobin, PCV - packed cell volume

Table 3 shows that there were poor correlations between parity and variables; age $(r=0.12)$, baby weight $(r=)$, $\mathrm{Hb}(\mathrm{r}=0.12), \mathrm{PCV}(\mathrm{r}=0.12), \mathrm{nRBC}(\mathrm{r}=0.18)$ for the hypertensive group Similarly there were poor correlations between parity and variables; age $(\mathrm{r}=0.42)$, baby weight $(\mathrm{r}=0.06), \mathrm{Hb}(\mathrm{r}=0.07), \mathrm{PCV}(\mathrm{r}=0.06), \mathrm{nRBCl}(\mathrm{r}=0.10)$ for the neonates delivered to non-hypertensive mothers. Table 4 shows that there was a statistical significant asso- ciation between mode of delivery and hypertension $\left(\chi^{2}\right.$ $=53.082, \mathrm{p}<0.001)$ It also shows that mothers who delivered by elective caesarean section were about 2 times more likely ( $\mathrm{OR}=1.95,95 \% \mathrm{CI} 0.06-0.33)$, and those that delivered by emergency caesarean section about 3 times more likely, $(\mathrm{OR}=2.49,95 \% \mathrm{CI} 0.04-0.18)$ to have hypertension than those that delivered through spontaneous vertex delivery (SVD). 
Table 3: Correlation between gestational age and parity with other characteristics for neonates of non hypertensive mothers

\begin{tabular}{|l|c|c|c|c|c|}
\hline Variable & Number & Mean & $\begin{array}{c}\text { Std } \\
\text { Dev }\end{array}$ & r & $\begin{array}{c}\text { p } \\
\text { value }\end{array}$ \\
\hline Gestational age & 100 & 38.64 & 2.05 & -0.12 & 0.837 \\
\hline Age & 100 & 30.65 & 5.34 & & \\
\hline & & & & & \\
\hline Gestational age & 100 & 38.64 & 2.05 & 0.05 & 0.611 \\
\hline Baby Weight & 100 & 3.25 & 0.48 & & \\
\hline & & & & & \\
\hline Gestational age & 100 & 38.64 & 2.05 & -0.15 & 0.144 \\
\hline HB & 100 & 14.76 & 2.34 & & \\
\hline & & & & & \\
\hline Gestational age & 100 & 38.64 & 2.05 & & \\
\hline PCV & 100 & 45.49 & 7.50 & & \\
\hline Gestational age & & & & & \\
\hline nRBC & 100 & 38.64 & 2.05 & 0.09 & 0.360 \\
\hline & 100 & 5.44 & 4.32 & & \\
\hline & & & & & \\
\hline Gestational age & Number & Mean & Std & rho & p \\
\hline Parity & & & Dev & & value \\
\hline & 100 & 38.64 & 2.05 & -0.13 & 0.191 \\
\hline Parity & 100 & 1.66 & 1.44 & & \\
\hline Maternal Age & & & & & \\
\hline & 100 & 1.66 & 1.44 & 0.42 & 0.000 \\
\hline Parity & 100 & 30.65 & 5.34 & & \\
\hline Baby Weight & & & & & \\
\hline & 100 & 1.66 & 1.44 & -0.06 & 0.583 \\
\hline Parity & 100 & 3.25 & 0.48 & & \\
\hline HB & & & & & \\
\hline & 100 & 1.66 & 1.44 & 0.07 & 0.581 \\
\hline Parity & 100 & 14.76 & 2.34 & & \\
\hline PCV & & & & & \\
\hline Parity & 100 & 1.66 & 1.44 & 0.06 & 0.887 \\
\hline nRBC & 100 & 45.49 & 7.50 & & \\
\hline & 100 & 1.66 & 1.44 & 0.10 & 0.313 \\
\hline & & 5.44 & 4.32 & & \\
\hline & & & & \\
\hline & & & & & \\
\hline & & & & & \\
\hline & & & & & \\
\hline
\end{tabular}

$\mathrm{r}$ - Pearson Correlation Coefficient, rho - Spearman Correlation Coefficient, nRBC -nucleated red blood cells, $\mathrm{Hb}$ - haemoglobin, $\mathrm{PCV}$ - packed cell volume

Table 4: Associations of characteristics with hypertension

\begin{tabular}{|l|c|c|c|c|}
\hline Variable & HTN & No HTN & & \\
\hline & $\mathbf{n}=\mathbf{1 0 0}$ & $\mathbf{n}=\mathbf{1 0 0}$ & $\chi^{2}$ test & $\begin{array}{c}\mathbf{p} \\
\text { value }\end{array}$ \\
\hline Family History of HTN & $\mathbf{n}(\%)$ & $\mathbf{n}(\%)$ & & \\
\hline No & & & & \\
\hline Yes & $65(47.4)$ & $72(52.6)$ & 1.135 & 0.287 \\
\hline & $35(55.6)$ & $28(44.4)$ & & \\
\hline Mode of delivery & & & & \\
\hline Elective C/S & & & & \\
\hline Emergency C/S & $25(71.4)$ & $10(28.6)$ & & \\
\hline SVD & $47(81.0)$ & $11(19.0)$ & 53.082 & 0.000 \\
\hline
\end{tabular}

HTN - hypertension, C/S - caesarean section, SVD - spontaneous vertex delivery 
Table 5: Regression on mode of delivery with or without hypertension

\begin{tabular}{|l|c|c|c|c|}
\hline & UOR & Sig & \multicolumn{2}{c|}{ 95\%CI for UOR } \\
\hline Mode of delivery & & & Lower & Upper \\
\hline Elective C/S & 1.95 & 0.000 & 0.06 & 0.33 \\
\hline Emergency C/S & 2.49 & 0.000 & 0.04 & 0.18 \\
\hline SVD & 1 & & & \\
\hline
\end{tabular}

\section{Discussion}

We noted a significant difference between the birth weight of babies from mothers with hypertension and that of non-hypertensive mothers. This finding agrees with a study which demonstrated a lower birth weights amongst pre-eclamptic women that had preterm deliveries when compared to their normotensive counterparts. ${ }^{11,12}$ These same findings were also corroborated by Philip et $\mathrm{al}^{13}$ who noted that high blood pressures among women during pregnancy are associated with small babies and high perinatal mortality.

The reason for this low birth weight among babies with low birth weight could be due to uteroplacental failure and hypoxic -ischaemia triggered by this high blood pressures.

These findings of ours was however refuted by Xiong et al14 who noted no differences in mean birthweight between women with gestational hypertension and women with normal blood pressure. He noted that, in China, most babies born to mothers with severe pre-eclampsia or pre-eclampsia and gestational hypertension had similar fetal growth to those born to non-hypertensive mothers. The reported difference could be racial factors or any factor that offers protective effects to babies of hypertensive mothers from Chinese decent?

When compared to neonates of non-hypertensive mothers, fetal haemoglobin levels, erythrocyte counts and haemoglobin levels were found to be higher among babies born to hypertensive mothers. However, it was observed that neutropenia, thrombocytopenia, and dysplastic changes in neutrophils, and erythrocytes on peripheral smears were found at a higher rate in newborns of hypertensive mothers. 15 Mothers with high blood pressure have increased placental peripheral resistance and increased placental ischaemic hypoxaemia which in turn shifts the oxyhaemoglobin curve of their babies to the right leading to increase erythropoiesis and this increases in $\mathrm{Hb}$ and erythrocyte counts.

We also noted that parity of women has no significant impact on weight of their babies. However, it is thought that a woman is more likely to deliver a heavier baby in African Health Sciences Vol 19 Issue 4, December, 2019 her second pregnancy than in her first pregnancy. Furthermore, it is a well-known fact that maternal physiological factors differ in two pregnancies and these differences have additional effects on birth weight. ${ }^{16}$. The effects of these observations tend to have a profound influence in predicting the likely change in birth weight between first and second pregnancies.19 We could not explain why we had no correlation between parity and birth weight of babies in our study.

With a regression analysis on mode of delivery and probability of having hypertension, we noted that those delivered by elective caesarean section (CS) were about twice more likely and those that delivered by emergency CS three times more likely to have hypertension than those that delivered through spontaneous vertex delivery (SVD).

Hirschberg et $\mathrm{al}^{17}$ also reported that women who deliver by CS were more likely to have hypertension when compared to women who delivered by SVD.

Furthermore, Louis et $\mathrm{al}^{18}$ in their study observed that CS was also associated with a higher risk of certain outcomes such as gestational hypertension, polyhydramnios, haemorrhage in early pregnancy, maternal care for known or suspected disproportion and long labor in subsequent pregnancy.

Pregnancy is a state of chronic volume and sodium overload that contributes to increased cardiac output, edema, and blood pressure elevation. While much of the accumulated sodium is rapidly lost during delivery, it may take some time for this salt and water homeostasis to return to antepartum levels in mothers with CS. ${ }^{19}$

We observed no relationship between parity and nucleated red blood cells of babies whose mothers are hypertensive when compared to their non-hypertensive counterparts. Ahmet 15 et al however had a contrary reportage, they noted increased in nucleated red cells of mothers with hypertension when compared to their controls.

\section{Conclusion}

Parity and gestational age of mothers with hypertension have no impact on birth weight and red cells of their neonates when compared with their non-hypertensive coun- 
terparts. However, mothers of babies delivered by elective and emergency CS were about 2-3 times more likely to be hypertensive than those that delivered through SVD.

\section{Conflict of interest}

None declared.

\section{References}

1. Gelband H, Liljestrand J, Nemer L, Islam M, Zupan J, Jha P. The evidence base for interventions to reduce maternal and neonatal mortality in low and middle income countries. Commission on Macroeconomics and Health (CMH) Working Paper Series. WG5 Paper. 2012;(5) http://library.cphs.chula.ac.th/Ebooks/HealthCareFinancing/WG5/Paper\%20no.WG5_5.pdf.

2. Regnault TRH, Limesand SW, Hay WW. Factors influencing fetal growth. Neo Reviews. 2001;2(6):e119-129. DOI:10.1542/NEO.2-6-e119.

3. Watson-JonesD, Weiss HA, Changalucha JM, Todd J, Gumodoka B, Bulmer J et al. Adverse birth outcomes in United Republic of Tanzania - Impact and prevention of maternal risk factors. Bulletin of World Health Organisation. Past Issue. 2017. 85(1):1-84

4. Institute of Medicine (US) Committee on Improving Birth Outcomes; Bale JR, Stoll BJ, Lucas AO, editors. Improving Birth Outcomes: Meeting the Challenge in the Developing World. Washington (DC): National Academies Press (US); 2003. 2, Reducing Maternal Mortality and Morbidity. Available from: https://www.ncbi.nlm. nih.gov/books/NBK222105/

5. Singh S, Ahmed EB, Egondu SC, Ikechukwu NE. Hypertensive disorders in pregnancy among pregnant women in a Nigerian teaching hospital. Niger Med J 2014; 55:384-8.

6. Steer PJ, Little MP, Kold-Jensen T, Chapple J, Elliott P. Maternal blood pressure in pregnancy, birth weight and perinatal mortality in first births: prospective study. BMJ. 2004; 329(7478):1312.

7. Magee LA, Helewa M, Moutquin J-M, Dadelszen PV. Diagnosis, evaluation, and management of the hypertensive disorders of pregnancy. J Obstet Gynaecol Can. 2008; 30 (3 suppl):S1-S2. doi: 10.1016/S1701-2163(16)32776148.

8. Carl H. Backes CH, Kara Markham K, Pamela Moorehead P, Leandro Cordero L, Craig A. Nankervis CA, and Peter J. Giannone PJ. Maternal Preeclampsia and Neonatal Outcomes. Journal of Pregnancy. 2011, Article ID 214365. DOI:10.1155/2011/214365

9. Onyiriuka A N, Okolo AA. Small-for-gestational age, 3044 ponderal index and neonatal polycythaemia: a study of their association with maternal hypertension among Nigerian women. Ann Afr Med. 2005;4(4):154-159

10. Helen C. Okoye, Lisa I. Eweputanna, Kaladada I. Korubo, Oseikhuemen A. Ejele. Effects of maternal hypertension on the neonatal haemogram in southern Nigeria: A case-control study. Malawi Medical Journal 2016; 28 (4):174-178.

R. Briggs C, Bain BJ.Basic haematological techniques. In: Dacie and Lewis practical haematology. Ed Bain BJ, Bates I, Laffan MA. 12 $2^{\text {th }}$ edition, Elsevier limited China 2017. 11. Xu Xiong, Nestor N. Demianczuk , L. Duncan Saunders, Fu-Lin Wang, William D. Fraser. Impact of Preeclampsia and Gestational Hypertension on Birth Weight by Gestational Age. American Journal of Epidemiology. 2002; 155(3): 203-209, https://doi.org/10.1093/aje/155.3.203 12. Chang-Ryul Kim, MD; Betty R. Vohr, MD; William Oh, MD. Effects of Maternal Hypertension in Very-Low-Birth-Weight Infants. Arch Pediatr Adolesc Med. 1996;150(7):686-691. doi:10.1001/archpedi.1996.02170320032005

13. Philip JS, Mark PL, Tina KJ, Jean C, Paul E. Maternal blood pressure in pregnancy, birth weight, and perinatal mortality in first births: prospective study. BMJ 2004; 329: 1312.

14. Xiong X, Fraser WD. Impact of pregnancy-induced hypertension on birth weight by gestational age. Paediatr Perinat Epidemiol. 2004;18:186-91 PubMed

15. Ahmet B, Orhan G, Emin K, Avni A, Okan O. Blood parameters changes in cord blood of newborns of hypertensive mothers. European Journal of Pediatrics 2013; 172: 1501-1509|

16. Wilcox MA, Chang AM, Johnson IR. The effects of parity on birthweight using successive pregnancies. Acta Obstet Gynecol Scand. 1996;75:459-3.

17. Hirshberg A, Sammel MS, Sindhu K. Are There Predictable Blood Pressure Patterns After Delivery in Women with Preeclampsia? Obtainable from http:// journals.lww.com/greenjournal/Abstract/2017/05001/ Are_There_Predictable_Blood_Pressure_Patterns.83. aspx. Accesed on $27^{\text {th }}$ Nov;2017

18. Louis J, Sevil T, George M, Ingeborg S, Volker Z, Karel K.Impact of caesarean section on mode of delivery, pregnancy-induced and pregnancy-associated disorders, and complications in the subsequent pregnancy in Germany. Ger Med Sci. 2016

19.Van Oppen A, Stigter R, Bruinse H. Cardiac output in normal pregnancy: a critical review. Obstet Gynecol. 1996;87:310-331

African Health Sciences Vol 19 Issue 4, December, 2019 